\title{
Applied Problems and Directions of Decisions of Green Technologies in Sustainable Development of Information Economics
}

\author{
Aliyev Alovsat G.
}

\begin{abstract}
.
The article is dedicated to the applied problems and directions of decisions of green technologies in sustainable development of information economics. The necessity of formation of the green economy and the reasons of transition to it in globalization and integration conditions are explained. The problems of greening of industrial, post-industrial, also information and knowledge-based economy are determined. The process of greening is represented as a new stage in economic development. International and regional conditions of formation of green economy are analysed. The importance of ICT in the greening of economic activity sphere is substantiated. Application tools, problems and directions of decisions of ICT in the greening of the new type of information economy are shown.
\end{abstract}

Key words: green economy, greening of industrial economy, greening technologies, green economy initiatives, green information economy, green computer networks, green ICT.

\section{Introduction}

At present, economic development achieved in many countries of the world is observed with negative manifestations such as violation of the natural balance of environment, increase in its pollution level, depletion of natural resources and climate change. Economy, main goal of which should serve to improve human's well-being, prevents the improvement of his life and does not fully provide his health [1]. Therefore direction of modernization in conditions of information society and formation of fourth industrial revolution components should be directed to such progressive innovative technologies that provide economic development that fertility and favorableness of surroundings, natural environment could be maintained and improved. Formation and development concept of green economy in this direction includes many directions such as resource-driven economy, the economy of the environment, green technologies etc. Energy efficiency of most production and service areas is primarily directed to economic growth. In fact, the main purpose is improving the living conditions of every person. For this, sustainable normal well-being conditions of future generations must be ensured by partially eliminating dependence on oil and gas resources and developing non-oil sector in the country. This issue makes it necessary to implement production and consumption across the country on the basis of ecological balance. Humanity has created many products and services on the basis of the traditional model of economy. However, for durable and sustainable economic development the greening of economy is necessary. Therefore, the signs of the emergence of a new economic model on the basis of green 
technologies are observed. In Azerbaijan modernization, innovation development, competitiveness of economy, provision of energy efficiency in the conditions of global economic crisis also should be directed towards the relative elimination of dependence on oil and gas resources in the country, development of other science, labour-intensive areas through the diversification of the economy. This issue is determined as the provision of sustainable development on the basis of the principles of the Information Society economy currently being formed. This makes implementation of economy greening technologies necessary in the country, as well as around the world. The National Program on Basic Sustainable Socio-Economic Development, characterizing environmental protection, serious consideration of ecological factors in the country's overall development was adopted in 2003 [2]. As a logical continuation of this program, one of the main targets of the National Strategy [3] for 2014-2020 for the Development of Information Society in Azerbaijan, also development concept [4] of Azerbaijan until 2020, adopted in 2012, is to achieve ecologically sustainable socio-economic development. In the recent years, covered by those adopted state documents, as well as in the coming years intended in strategic roadmaps for the development of economic sectors, greening of the economy, the use of alternative energy sources will be further accelerated. Therefore, through the wide introduction of greening technologies in the new information society conditions, the fertility, availability of the surrounding natural environment should be maintained and improved. In this case, economic greening technologies will become a decisive factor both for economic growth and for people themselves to live better and their healthy existence.

\section{The problem of greening of industrial and post-industrial economy and environmental protection.}

The green economy is a new direction formed in the last two decades in economy science. Such economy is an economy that depends on the natural environment as a part of it. The green economy concept incorporates ideas of many directions such as postmodernism, resource-oriented economy, ecological economy, environmental economy, green politics etc. existing in the system of socio-economic sciences.

The Economic and Social Commission for Asia and the Pacific, which represented Azerbaijan, Georgia, Kazakhstan, Kyrgyzstan, Russia, Tajikistan, Uzbekistan and Turkmenistan from post-Soviet countries, has played a major role in the formation the green economy concept. In 2005, at the initiative of this commission a strategy that firstly incorporated the four priority areas of green development has been adopted: 1) rational models of consumption and production; 2)greening of institutions and markets; 3)sustainable infrastructure and 4)green taxes and budget reforms. Further, two more directions have been added: 5)investment to the natural capital and 6)ecological efficiency indicators.

The United Nations Environment Program (UNEP) made an initiative on green economy in 2008. Its target was to form the economy of the future. In general, the green economy initiative is based on three main principles such as 1) evaluation and development of natural resources at national and international levels, 2) provision of 
employment and appropriate policy through the creation of green jobs, 3) use of market mechanisms for achievement of sustainable development $[5,6]$.

In "the Declaration on the Ecologically Friendly Development," adopted by the Organization for Economic Co-operation and Development (OECD) in June 2009 the determination of consolidation of the state efforts in the field of the future realization of green development strategy and sustainable regulation of green investments and natural resources was expressed [7]. In June 2010, in the Declaration of the "20th Group" of State Leaders in Toronto it was announced that for sustainable and more balanced development, from now on the evaluation methods taking into account social and environmental consequences of economic development should be used [8].

At the High Level Conference on Sustainable Development of the UN which took part in Brazil in 2012 (Rio + 20) "green economy in the context of sustainable development and poverty eradication" was one of the two main issues. In this case, it was suggested to carry out additional researches to determine how green economy will make the process of transition to the sustainable development accelerate [9, 10]. The problems of the formation and development of green economy, besides many issues of resource-oriented economy, also covers the problems of ecological economy and green technologies. The brown economy being the opposite of the green economy concept is based on using more resources, low energy efficiency, dependency on non-sustainable energy sources, and high level of climate risk. International organizations such as the Organization for Economic Co-operation and Development (OECD), the United Nations Environment Program adopt green development and green economy as a process prescribing consumption and manufacturing of products and services providing ecological safety, as well as investments on green development and technologies [5]. At this view, while providing ecological sustainability, factors of economic development, employment and reduction of unemployment are envisaged in detail. Formation of the green economy is mostly considered as one of the directions of getting out of the global financialeconomic crisis. Green economy concept is not fully replaced by sustainable development concept. However, achieving sustainability also almost depends on proper formation of the economy. Over the past decades, many new resources have been created by humanity on the basis of the brown economy model. However, the greening of the world economy is necessary for development of sustainable economy. Nowadays, signs of the emergence of a new economic model are observed much in the world and in some countries. The global economic crisis also made the formation of green economy even more necessary. In the anti-crisis programs developed by many countries, the ecological component already occupies one of the most important places. At present, there is no concept that is accurately defined and accepted by everyone, of what processes green economy covers. Individual countries also accept this process in some different ways. In fact, it is normal that taking appropriate steps in the field of green economy nowadays differs from state to state. Because there is a great difference in terms of quality between human capital of economically developed countries and human capital of developing or newly industrialized countries. This difference also shows itself in the green economy events of the relevant countries. The necessity of transition to green economy is due to three main reasons [6]: 1) constant expanding and strengthening of human impact on the limited area is impossible. Increasing the impact through space 
and ocean depths at the present stage and in the near future is also very limited; 2)natural resources on the Earth that are not recoverable are not inexhaustible. In conditions where the number of population is constantly growing and their needs are expanding, the satisfaction of these needs and the fair division of existing benefits becomes a major problem; 3)it should be considered that any negative process that occurs as a result of human activity in any part of the globe can also have an impact on other locations over time. Thus, it becomes clear that new approaches to the solution of the ecological, social and economic problems that mankind face in the modern era should be used. The transition to the green economy mainly covers three periods [7]: I period - covers the time up to 2020, and includes measures such as educating people and developing human capital. II period - covers 2020-2030, and considers formulation of the elements of the green economic system. III period - dates back to 2030-2050. During this period the green economic system already produces a result and sustainable development is provided. Regardless of the transition period, the greening of the economy divides the problems existing in the society into four main categories: ecological, intellectual, political and ethical. Therefore, according to these categories appropriate terms and conditions should be created for transition to green economy. These include national normative-legal documents, politics, financial aids and incentives, world market, legal infrastructure, commodity turnover and financial assistance etc. Along with these it needs to be considered that in the report of the United Nations Environment Program (UNEP), "Pathways to Sustainable Development and Poverty Eradication" [5], 10 main sectors that need to be invested on were divided: agriculture, construction, power supply, fishing, forestry, energy efficiency, tourism, transport, waste management, water resources management. The characteristics of those sectors should not be overlooked on the stages of transition to green economy.

\section{The greening stage and means in sustainable development of information economy}

There are many problems facing the ICT, IS, that are the basis of knowledge and skill in providing the development based on human potential which is the main priority of the $21^{\text {st }}$ century. An important direction of the modern era is the preparation of citizens able to serve to the development based on knowledge, science and advanced technologies. The tendencies observed in different parts of the planet have shown that protection of life and provision of long-term development on the Earth requires the formation of new priorities in the economic activity of a person. The most basics of them are green economy, green lifestyle and green mentality, green thinking, green intelligence, interacting with the environment and providing sustainable development. Formation of the green economy is the main way of both the protection of the environment and provision of long-term development based on the existing natural resources and knowledge. At present, new tendencies and new challenges have emerged in the sustainable development based on human potential. These can be characterized as green economy, green lifestyle, green consumption, or green behaviour. Of course, first of all in green economy and green production, the activity of a human who considers nature laws, doesn't negatively affect the environment, uses the natural resources 
efficiently and with high savings, in industry and agriculture is considered more basic and important [6-12]. At the current stage, green knowledge and skills is of particular importance. The professionals prepared for the labour market of information and knowledge society should respond to these challenges both as professional and citizen. Sustainable and long-term development, which serves the interests of future generations, can be provided only in the conditions of the preparation of professional specialists on the basis of these principles. Sustainable and long-term development, which serves the interests of future generations, can only be provided in the conditions of the preparation of professional specialists on the basis of these principles.

\section{Economic mechanisms for the formation and regulation of green economy in new economic conditions}

These can be attributed to the mechanisms of transition to the formation and development of the green economy: 1) evaluation in accordance with the principles of sustainable development; 2) making appropriate change to the taxation system, transition from labour force taxation to pollution taxation; 3) public procurement policy which considers the production of ecological products; 4) increasing the volume of public investment in environmental infrastructure in accordance with the principles of sustainable development; 5) government support for research and development of ecologically clean technologies; 6) social strategies directed to the provision of adaptation between economic strategies. In addition to the above, recommendations about the transition to green economy policy and conditions have also been developed by UNEP. These conditions include [8, 9]: 1) creation of efficient normative-legal bases of transition; 2) priority of government investments and expenses in areas that stimulate the greening of the sectors of the economy; 3) reduction of expenses on areas where natural capital depletes; 4) application of taxes and other market mechanisms for stimulation of green investments and innovations; 5) investing in increase of training and education; 6) strengthening international cooperation. These conditions once again confirm the necessity of strengthening the role of the state in the transition to the green economy and the improvement of state policy. As we can see, the role of international cooperation and assistance among the conditions of transition to green economy is great. So that international ecological agreements facilitate and stimulate the transition to green economy. Multilateral ecological agreements can also play an important role in the solution of global ecological problems, ecologicalization of economic activity. UN Framework Convention on Climate Change can have more impact on the transition process to the green economy than many international ecological agreements [8].

While highlighting the experience of different countries in the development of green economy, the reforms they have implemented and mechanisms they have used need to be reviewed. Thus, each country has its own peculiarity in this field. The following options of the mechanisms that can be used in the development of green economy can be noted [14-16]: 1) ecological tax reforms and tools (for example, carbon tax, tax exemptions and cuts); 2) fines for intensive pollution; 3) 3) green subsidies, grants, loans for the award of environmental projects; 4) elimination of granting subsidies to environmentally harmful activities; 5) direct public expenditure (for example, 
organization of research and development (R \& D) activity for ecologically clean infrastructure or clean technology), indirect support (for example, public guarantees etc.). For the development of the green economy the UK uses a discounted tariff called the Feed-In Tariffs scheme (FITs) in this direction [17]. In Germany, ecological tax (Eco Tax) reform is used for the development of the green economy [18]. When using green subsidies as a tool, external environmental factors (globalization, international competition, domestic market conjuncture, especially consumer psychology etc.) should be taken into account $[19,20]$.

\section{Analysis of the international and regional initiatives and research on the formation of the green economy}

The EDP has repeatedly taken different initiatives on formation of the green economy. Governments in the United Nations Sustainable Development Conference ("Rio + 20") have recognized that the green economy is a very important tool for sustainable development. The Rio +20 Declaration also noted the implementation of green economic policy with the information exchange and transforming potential opportunities into reality. The initiatives on implementation of the green economy at the international level is mainly reflected in the following areas:

- International green economy platforms and forums,

- Main participants on international green economy,

- Main international green economy programs,

- $\quad$ Funds/mechanisms/objects on international green economy.

Up to 60 international initiatives on the development of the green economy have been attempted so far. 14 of them account for international forums. The main targets of the platforms in these forums are information exchange, science and knowledge management, global climate change. The shown platforms are the following:

- Green Growth Knowledge Platform - World Bank, Global Green Growth Institute- GGGI, Organization for Economic Cooperation and Development (OECD);

- The Green Industry Platform - UN Industrial Development Organization UNIDO, UNEP;

- The Green Growth online e-learning facility - UN Economic and Social Commission for Asia and the Pacific - ESCAP;

(WIPO);

- $\quad$ The Climate Change Knowledge Portal - World Bank;

- $\quad$ Climate Information Platform - UNDP and with some partners;

- UN Sustainable Development Knowledge Platform - UN Department of Economic and Social Affairs (UNDESA) etc.

Participants with extensive work in the implementation of the international green economy are mainly Developed Countries of European Union, European Union agencies, influential NGOs, brain centers, consulting companies and some private sector 
representatives. Recently, the following new participants have been involved in this process:

- $\quad$ The Global Green Growth Institute (GGGI);
- $\quad$ The Partnership for Action on Green Economy (PAGE);
- $\quad$ United Nations Industrial Development Organization (UNIDO);
- $\quad$ Green Growth Action Alliance;
Green Economy Coalition.

Climate Development Knowledge Network (CDKN - funded by Great Britain and Netherlands), ClimateWorks and Project Catalyst (funded by private investors), Global Climate Change Alliance (funded by European Union) etc. can be shown as examples to the organizations acting on climate change.

In addition, there is the Kyoto Protocol (UNFCCC), which was adopted in 1997 and came into force in 2005, includes developed and developing countries, and it is an international contract defining the mandatory commitments of industrial countries to reduce the emission of greenhouse gases. The duration of the contract was extended to 2020 at the international conference in the capital of Gatar, Doha. This decision, approved by approximately 200 countries, only covers developed countries. In these countries, the emissions of greenhouse gases at the global level are less than $15 \%$. The United States of the most atmosphere polluting countries never approved the original protocol of 1997. At the moment, there are no signatures of countries that pollute the atmosphere the most, such as the United States, China and India. At the Doha Conference, work on a larger scale plan that will be able to cover all countries and replace the Kyoto Protocol was planned by 2015. Azerbaijan here, as a developing country, has no legal obligation in reducing of the greenhouse gas emissions to the environment.

On December 16, 1972, at the 27th session of the United Nations (UN) General Assembly, the celebration of World Environment Day was announced in the capital of Sweden, Stockholm. Also, at this session of the General Assembly, the new UN organization - United Nations Environment Programme (UNEP) has been created. Every year the "World Environment Day" is held by this organization.

The reason for holding this day was the appeal addressed to the Secretary-General of the UN on May 11, 1971 with the signature of 2200 scientific and cultural figures of 23 countries of the world. 5th of June "World Environment Day" has been celebrated since 1973. The main purpose of the day is to focus on the protection of the environment in all member countries, to carry out awareness activities in order to increase ecological consciousness among the population and to emphasize the importance for everyone to fulfill their own commitment for the solution of ecological problems.

It can be considered that there are more reasons to celebrate this day because of disruption of ecological balance and environmental pollution. During processing, waste is thrown directly into the environment, programlessness of the cities in the fields of industry, energetics and transport creates sick and dead ecology. Soil, water and air balance is violated. As a result, forest area, vegetation, the diversity and richness of the 
wildlife decreases. The state of cleanliness of the country, harmful emissions to the sea, deforestation cause future generations, children to live ill and incomplete.

The following can be mentioned among the major international organizations operating on green economy [5]: 1) UN Environment Programme (UNEP); 2) UN Development Programme (UNDP); 3) UN Food and Agriculture Organization (FAO); 4) International Union for Conservation of Nature; 5) World Wildlife Fund; 6) International Green World etc. The United Nations has a leading role in resolving issues related to the protection of the biosphere. In addition, some main bodies and specialized organizations of UN also carry out work related to the green economy issues to some extent. At the beginning of the XXI century at the Global Ecological Perspective - 2000, adopted by UNEP with the participation of more than 850 experts and more than 30 ecological organizations of the world, it has been decided the solution of environmental problems in the new millennium is possible only through joint efforts [8]. Among the main entrepreneurs of the ongoing programs related to the green economy, there are also active countries like Norway, Denmark, Australia, Germany, Spain and Sweden along with the above mentioned major organizations. At present, analysis, research and investment for the development of the green economy mainly cover the following areas:

- $\quad$ Funding services: grants, project financing, etc.;

- $\quad$ Scientific research services: basic knowledge bases etc.;

- Information service: information exchange, the development of education, science management etc.;

- $\quad$ Technology transfer service: technology exchange etc.

Analysis shows that the area which is more supported by the green economy programs is information sector (64\%) and the less supported area is the technology transfer sector, which is only $14 \%$. According to these indicators, it can be said that there should be more support for scientific research so that consequently technology transfer would be implemented more quickly. Because, in order to achieve green economy in countries there is a need for modern and scientifically-based technologies.

Speaking about the experience of different countries in the development of the green economy, it is needed to review the reforms they implement and mechanisms they use. Thus, each country has its peculiarity in this field. The following options of the tools which can be used in the development of the green economy can be noted: ecological tax reforms and tools (for example, carbon tax, tax exemptions and cuts), fines for intensive pollution; green subsidies, grants, credits for ecological project award; elimination of granting subsidies to ecologically harmful activities; direct government expenses (for example, organization of research and development (R \& D) activities for ecologically clean infrastructure or clean technology etc.

Great Britain uses FIT (Feed-in-Tariffs scheme) discounted tariff in this direction for the development of the green economy. According to the essence of this tariff, if someone, for example, places a solar panel or wind energy turbine on their roof, this subsidy type is applied to those persons. That is, that citizen is paid a certain amount of money and plus the subscriber gets free from the energy costs he had to pay every month, because he already uses both ecologically clean and renewable energy. 
In Germany, the ecological tax for the development of the green economy (Eco Tax) is used and its results are the following:

- $\quad$ energy saving and its more efficient use;

- $\quad$ free use of sulfur fuel;

- $\quad$ more investment in renewable energy sources;

- the development of energy-saving production (for example, production of fuelefficient cars);

- reducing fuel consumption of newly produced cars up to $20 \%$, further reduction of road construction expenses;

- $\quad$ increasing the amount of water heaters up to twice as a result of the activity of solar energy economy and creating new workplaces in this sector (for example, according to the report of German Environment Agency (GEA), in 2003 250,000 new workplaces were created in Germany as a result of the application of this tax).

This type of tax helps to achieve a reduction of $\mathrm{CO}_{2}$ emissions up to $40 \%$ (compared to the 1990s) until 2020, which is one of the main goals of Germany and the awareness on climate protection.

When using "green" subsidies as an instrument, external environmental factors (globalization, international competition, domestic market conjuncture, especially consumer psychology, etc.) should be taken into account, otherwise the results may be unexpected. For example, Sweden has been the world leader in recent 3 years in solid state subsidies such as tax exemptions on the sale of "ecomobile" (ethanol-powered specific vehicles) per capita, cash bonuses and car insurance benefits for buyers of such cars. Nevertheless, in 2010 only because of this transport $\mathrm{CO}_{2}$ emissions increased by 100,000 tons. Because despite the reduction in the CO2 emissions per vehicle, the total number of kilometers traveled has increased, i.e. under favorable conditions, people traveled more often in such cars. This is called Jevons paradox (rebound effect) in economic literature. The Jevons paradox - the increase in consumption efficiency of any resource as a result of technological progress increases the demand for this resource.

Another instrument of green fiscal policy, which has already been applied in different countries of the world, is carbon tax (or carbon emission tax). Carbon tax is a tax on the reduction of carbon emission, which is one of the most important sources of global warming and climate change, and occurred from the combustion of fuels such as oil, coal and natural gas. This type of tax does not damage the state budget as it is applied to environmentally damaging areas and also positively affects the problem of poverty. States such as the Netherlands, England and Germany can maintain this balance by reducing other tax burdens and increasing the tax burden associated with the environment. Fighting by taxes, can be an effective way to protect both natural ecosystems and biodiversity.

Analysis of the situation in Azerbaijan in the field of green economy formation. Along with the oil industry of Azerbaijan, the development of the non-oil sector, progress in the regions, the integration into the global economic space and the increasing competitiveness of the economy have become irreversible. At present, a successful policy is being taken to establish green economy as a component of sustainable development in the country. There is plenty of ground for implementation of a perfect environmental 
policy. In accordance with the decisions of the Rio+20 and Johannesburg Summits, Azerbaijan regularly implements the improvement of ecological policy and legislation [13]. Ecological measures include adoption of state programs and laws, application of new management principles, expansion of national park networks, further improvement of people's drinkable water supply, waste management and certain work on environmental protection area. The following principles of the environmental legislation in Azerbaijan envisage the development of the green economy [21]: 1) mutual solution of socio-economic, moral and spiritual problems; 2) ensuring sustainable use of natural resources; 3) conservation and protection of ecological balance; 4) ecosystem approach to the regulation of the environmental protection and use of natural resources; 5) sanctions on environmental pollution; 6) payment for the use of nature; 7) ensuring ecological balance in the territories and rehabilitating damaged natural ecological systems; 8) efficient use and restoration of natural resources, application of economic stimulation of the use of nature and environmental protection; 9) ensuring the protection of the biodiversity of the environment; 10) responsibility for violation of the legislation on state control and environmental protection; 11) assessment of the damage caused to the environment; 12) ecologically sustainable socio-economic development, protection of human life and health; 13) participation of the population and public associations in the field of environmental protection; 14) international cooperation in the area of environmental protection, adaptation of of environmental legislation with European legislation and international agreements $[22,23]$.

About evaluation of greening level in sustainable development of economy. The National Green Economy Index (NGEI) is proposed as the aforementioned indices can not fully reflect the current situation. The main indicators for the calculation of NGEI are: environmental quality, renewable energy, soil conservation, green tourism, green GDP, environmental protection costs, greenhouse gas emissions, and innovation index. The environmental quality index, characterized by the key indicators reflecting the development of the national green economy, includes: air quality, water, soil, biodiversity, environmental protection, and environmental damage. Based on the synthesis of the proposed options, both from the national and regional aspects we propose the Regional Green Economy Index (RGEI) and sub-indexes affecting its formation [18-22]:

1. Environmental protection level (EPL);

2. Specific weight of green GDP (GGDP);

3. Specific weight of renewable energy (SWRE);

4. Ecological Recovery Costs (ERC);

5. Application level of green technologies (ALGT);

6. Industrial and household wastewater treatment level (IHWTL);

7. ICT Impact Index on Greening (ICTG);

8. Science-education-technology index (SETI);

9. Greening index in social-cultural spheres (GSCS);

10. Ecological Use Index of Natural Resources (EUINR).

Thus, it can be denotes as follows:

RGEI = F (EPL, GGDP, SWRE, ERC, ALGT, IHWTL, ICTG, SETI, GSCS, EUINR) (1)

Here, $F$ is an analytical expression of the dependence on the sub-indexes of RGEI. 
It should be noted that, the quality of the environment in any particular region can be characterized by the synthesis of air, water, soil, biodiversity, pollution, noise, and other quality level. These studies can serve to improve the solution of existing problems in the green economy in the future. The solution of modern problems related to the formation of green economy requires a multidisciplinary approach. Therefore, scientific, theoretical, ecological, economic, technological, social, legal, infrastructural, medical, chemical, biological, management and innovation problems of the green economy should be comprehensively studied separately.

5.ICT application directions and problems in greening of information economy. Observations show that determination of the efficient formulation and development directions of the green economy can be implemented based on application of modern information technologies. Specifically, one of the directions of the greening of economy is informatization of the economic processes and activities of governing bodies. The importance of activities, knowledge and skills in the field of green economy can be understood from the analysis of the effective use of natural resources. The state of the economy of any country can be estimated by the value of the products and services produced, the amount of energy consumed to obtain the national product. This indicator used in the international statistics shows how saving production is, based on modern technological achievements and the professionalism of the working force at this level [18]. The issue of efficient use of natural resources should first of all be carried out based on the correct economic analysis and assessment. And this, as mentioned, makes application of the modern information technologies inevitable.

In many countries economic growth is more based on more exploitation of natural resources - soil, water, forest, energy resources, various ores etc. Therefore, limited reserves of natural resources cannot provide sustainable development of the planet population by the maintenance of modern economic tendencies. As the UN experts point out, economic model with features such as ecological disadvantage and social injustice is quite far from green economy. The most important issue for the transition to green economy is the protection and increase of natural resources bringing economic and public benefit. Increasing the efficiency of their use and keeping them for future generations is of particular importance [19].

Protection of ecosystems and the services brought by them is a priority direction of green economy. In the international economy these services are often associated with terms such as payments for ecosystem services that are new for the world, ecological donors, compensation mechanisms, and debts for nature exchange. A number of fundamental international researches are also dedicated to the economy of ecosystems. Applied works on inclusion of ecosystem services into economic practice, including the financial sector also emerged. Such works, analyses and appropriate management decision-making is based on the analysis of the initially collected large volumes of data with the use of modern ICT methods [20-26].

In the current period increasing the efficiency of use of energy and water resources is a national and global priority. As the measures being implemented and projects being developed cover all areas and subjects of the country's life, the application of the newest ICT technologies in these processes contributes to the achievement of important new results. 
Appropriate measures should be implemented in time for the timely prevention of the dangers of the formation of green economy and the elimination of consequences. Taking such measures requires, first of all, carrying out economic analysis, evaluations, and predictions based on correct information. Therefore, appropriate conditions and mechanisms should be created for application of the modern ICT technologies in the specified areas.

From the green economy towards the green information economy. In modern age the main issue of the formation of IS, at first glance, implies comprehensive application of information technologies, enlargement of electronic services provided to the population. In fact, IS construction, having a broader scale, covers the complex informatization of entirely all regions of the country, production and non-production areas, the activity of local government structures, the activity of civil society organizations. Therefore, IS construction should be viewed as a process of informatization of the society on macro and micro levels. In this case, carrying out a number of preventive measures in IS construction as a whole in the direction of greening is imperative. These measures can be grouped in several directions.

At present, according to the development tendencies of the world industrial economy is mostly developed on the basis of green technologies. The largest greening way of the industrial economy goes without informatization, through ICT (Figure 1). 


\section{ICT based greening directions}

Application and development of saving technologies through efficient distribution of thermal energy resources

Efficient use of resources through the creation and application of new innovative technologies in all sectors of the economy

Extensive use of ICT in the forming of green lifestyle and thinking, organizing of cultural-educational, mass-propaganda work

Wide use of information and communication technologies capabilities in eliminating emergency situations

Efficient organization of work and efficient use technologies of resources in agricultural sector through ICT

Application of ICT in the construction sector, transport, industrial areas, management work, efficient use and deployment of resources

The use of the ICT factor in the management of urban farming, organization of the activity of municipalities, in the use of the housing fund

Use of ICT capabilities in ecological field, nature protection, geological surveys, tourism field

Figure 1. Some directions on greening of economy based on ICT

There is enough of greening potential in the direction of automatization of production, informatization of management processes. Therefore, the process of greening of the industrial economy should firstly be considered in the context of the informatization of the economy. In other words, the application of new greening technologies of a new economy - information economy with innovative methods should be achieved. And this, as a result, is the formation and development of the green innovative information economy (Figure 2).

ICT problems in the greening of information economy. At present, the world ICT industry attaches great importance to its renewal and production on the basis of green technologies. Relevant scientific research is carried out, projects are implemented, green technologies are developed in this area. Progressive innovative technologies are being developed and applied in scientific and technical spheres such as Green ICT, green computer mouse, Green ICT Innovations, Sustainable Computing and Communications, 
ICT for sustainability, Designing sustainable ICT, Green Computing Networking, Smart Cities and Green ICT Systems, Green Data Centers, Green ICT Conferences, Green eDevices, Green Biomed, Green media, Green ICT Media Library, Green ICT in Government, Greenmetrics, Healthcare and Green ICT, Global Green ICT Update, Green ICT Art etc.

Besides these, as the innovative information economy is formed, many problems arise that they can be solved through the development and application of the relevant greening technologies. For example, creating of anti-radioactive technologies is one of the main problems of the modern era. Thus, informatization of society, massive internetization, wide application of wireless networks, constant use of wireless equipment, fast electronicization, internet of things, application of cloud, fog technologies increases the radioactivity degree of the environment, can cause certain damage to human health. Therefore, development and application of appropriate healthimproving anti-radioactive technologies in parallel in the construction of information society is inevitable. Besides, in the current abundance of information new requirements are being suggested to Big Data technology. Thus, the use of different purpose computer and information networks more by people creates an abundance of increasingly growing information. As a result, the volume of information resources grows extremely and it becomes difficult to separate unnecessary information from necessary one. This causes spending extra time financial resources. The abundance of information creates excessive information wastage after a certain period. Non-cancellation of it in time causes serious problems. Although the information about any person, organization is in digital form, its maintenance, systematization, processing, protection, and transmission technologies require reconsideration from the perspective of greening technology. Information culture, information use, and information retrieval methods should also be re-developed based on those requirements. Relevant technologies for the effective and productive use of large volumes of data should be developed. Despite all this, there is a problem of lack of information along with the abundance of information in society. Timely access to the most necessary information in relevant areas - transport, agriculture, trade, medicine etc. creates enough of "real waste" of industrial economy and causes extra time and financial costs. 


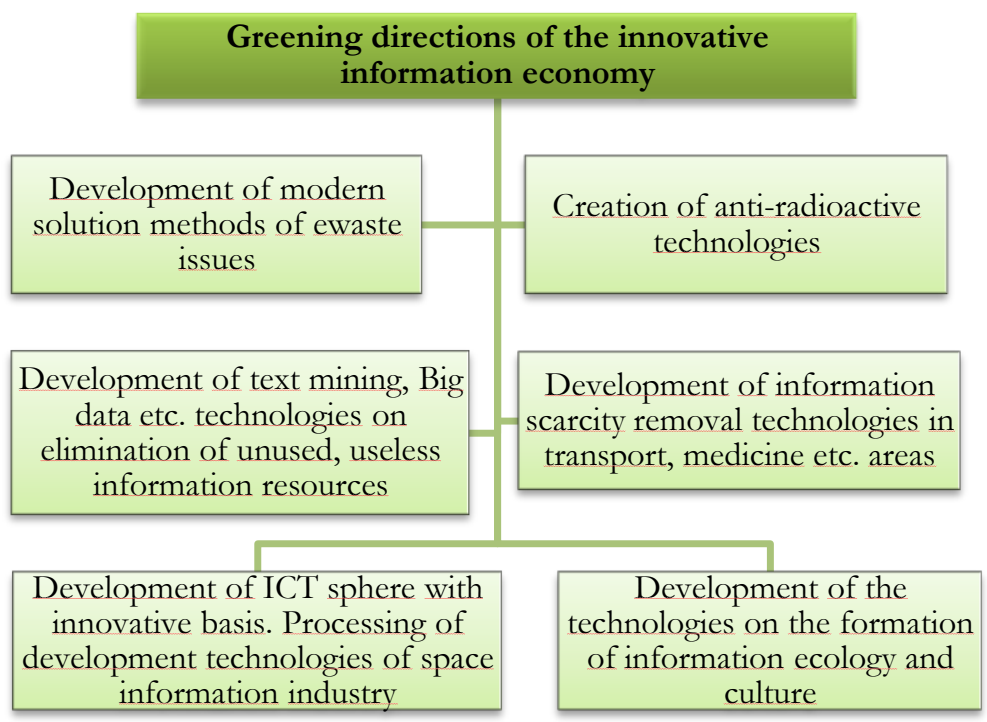

Figure 2. Greening directions of innovative information economy

Therefore, rapid and intensive development of the informatization process is desirable and is a driving force to the development of the society. At the same time, the process of informatization is one of the greening technologies implemented in various sectors of industrial economy. One of the main undesirable problems of IS construction is electronic waste, which is a logical consequence of mass informatization and failure of their timely utilization. Although there are quite progressive methods and experiences in the world practice in this direction, there are still problems which are very important to meet in this area. The timely solution of these problems directly serves the physical greening of innovative information economy.

\section{Conclusion}

There are many problems facing ICT, İnformation Society in providing longterm economic development and ecological balance. One of the main problems is development and use of green economy technologies. Therefore, Azerbaijan economy and society firstly should use greening technologies of post-industrial economy in the most efficient way. Besides, by diversification of the economy, the development of nonoil sector should be achieved. Also by using widely the most modern high technologies and ICT, the greening of the economy itself of the Information Society should be implemented. In new economic conditions the advantages of green economy are more than its disadvantages. Therefore, green economy can be viewed as a new stage of the modern information and knowledge economy and a way with no alternative leading to sustainable development. 


\section{References}

1. Dinda S. A., Theoretical basis for green growth // International Journal of Green Economics, 2014, vol. 8, issue 2, pp. 177-189.

2. State Program on the use of alternative and renewable energy sources in the Republic of Azerbaijan. October 21, 2004,

http://www.carecprogram.org/uploads/docs/AZE-Renewable-Energy-Strategy-az.pdf

3. "National Strategy for the development of Information Society in the Republic of Azerbaijan for 20142020", Baku, April 2nd, http://www.president.az

4. Development Concept "Azerbaijan - 2020: Outlook for the Future". Baku, 2012, www.president.az

5. Wabwoba F., Omuterema S., Wanyembi G.W., Omieno K. K., Green ICT readiness model for developing economies: Case of Kenya // 22(IJACSA) International Journal of Advanced Computer Science and Applications, 2013, vol. 4, No.1, pp.51-65.

6. United Nations Environmental Programme: Green Economy, http://www.unep.org/greeneconomy

7. Alguliyev R.M., Aliyev A.G. Greening the economy as a new stage in the development of the information society. Information Society Problems, 2016, №1, p.3-11

8. Yashalova N.N. "Green" economy: issues of theory and direction of development. National interests: priorities and security. 2013, Issue 11, pp.33-40

9. United Nations. Rio 20+. In Proceedings of The United Nations conference on sustainable development, Rio+20, Rio de Janeiro, Brasil, 2012. https://sustainabledevelopment.un.org/rio20

10. Udapudi S., Fakkiresh S. S., From Stockholm to Rio to Rio+20: Green Economy and the Road A. American international journal of research in humanities, arts and social sciences, March-May 2015, vol. 10 (1), pp. 65-73.

11. Wysokińska Z.T. To A Green Economy in the context of selected european and global requirements for sustainable development. VERSITA-2013-0034, pp.203-226.

12. Gholami Kand Sari Ali, Introduction to the green economy and its impact on the environment. Arabian Journal of Business and Management Review (OMAN Chapter) Vol. 2, No.6, Jan. 2013, pp.1-5.

13. Pociovălișteanu D.M., Corti I.N., Aceleanu M.I. Șerban A.C. and Grecu E. Employment policies for a green economy at the european union level. Sustainability, 2015, №7, pp. 9231-9250.

14. National Program on Ecological Socio-Economic Development in the Republic of Azerbaijan, February 18, 2003, http://www.eco.gov.az/az

15. "National Strategy for the development of Information Society in the Republic of Azerbaijan for 20142020", Baku, april 2nd, http://www.president.az

16. Strategic Roadmaps for the national economy and main economic sectors, Baku, december 6th, 2016, http://www.president.az

17. Global "green" new course. UNEP Report, march 2009 http://www.uncclearn.org/sites/default/files/inventory/unep90 rus.pdf

18. Measuring progress towards a green economy. http://www.gwp.org/globalassets/global/toolbox/references/measuring-progress-towards-aninclusive-green-economy-unep-2012.pdf

19. Green economy. Company re: Green lab, an electronic resource, http://www.regreenlab.ru/ru/greeneconomic

20. Towards a Green Economy: Pathways to sustainable development and poverty eradication. http://drustage.unep.org/greeneconomy/resources/green-economy-report

21. Bobylev S.N, Zakharov V.M. Green Economy and Modernization. Ecological and economic foundations of sustainable development. Towards a sustainable development of Russia. 2012, №60, p. 40-52

22. Alekberov U., "Green" economics and vocational education: a new stage of civilization - a path leading to ecological civilization, Azerbaijani teacher, 2010, №25, www.muallim.edu.az

23. Gasymli V., Veliyev Z., Humbatov M. and others. Green Development: Energy Efficiency and Alternative Sources. Strategic research center under the president of the Republic of Azerbaijan. 2014, 144 p.

24. Potravny I.M, Novoselov A.L., Gengut I.B. Formalization of the general model of the green economy at the regional level. Economy of the region. 2016, Vol.12, no2, p.438-450 
25. Gurieva M.A, Simarova I.S. Methodical approach to the assessment of the development of the "green" economy in the economic space. Science and business: the development. 2016, №10(64), p.90-103 26. Madiyarova E.S., Madiyarova K.Z., Abdiev B.A., Ezhebekov M.A. Green Economy: its optimization and modeling. Mediterranean Journal of social sciences, 2015, vol 6, no.4, pp.186-192. 